\title{
Military Alliances and Reality of Regional Integration: Japan, South Korea, the US vs. China, North Korea
}

\author{
Young-Wan Goo \\ Chungbuk National University, Cheongju, South Korea \\ Seong-Hoon Lee \\ Cheongju University, Cheongju, South Korea
}

\begin{abstract}
East Asian military security is of overarching importance in the economic integration and prosperity in this region. This study analyzes how South Korea and Japan consider the U.S. as a military ally in the context of the China-North Korea alliance by using the iterative Seemingly Unrelated Regression(SUR) method in estimating defense goods demand functions. The findings are that Japan considered the U.S. to be a closer ally than the U.S. did during 2000 2005 and South Korea may regard the U.S. as a closer ally than vice versa. The U.S. regards Japan as a closer ally than Korea. South Korea's demand for defense goods has not been increased by the threat from the China-North Korea alliance but American and Japanese demand has recently been increased by the threat, implying that South Korea has not regarded the China-North Korea alliance as a significant threat whereas that Japan and the U.S. have recognized the military alliance as a serious one.
\end{abstract}

\footnotetext{
* Corresponding Author: Young-Wan Goo; Department of Economics, Chungbuk National University, 410 Seongbong-ro, Cheongju, Chungbuk, 361-763, South Korea, Tel: +82 432612217, Email: ywgoo@cbnu.ac.kr Co-Author: Seong-Hoon Lee; Department of Economics, Cheongju University, 298 Dasung-ro, Cheongju, South Korea, Tel: +82 432298179, Email: seonghoon@cju.ac.kr
}

Acknowledgements: This work was supported by a research grant of the Chungbuk National University in 2012. 
JEL Classifications: H410, H560, O530

Key words: Military Alliance, Defense Goods, Threat Elasticity, Spill-In Elasticity (SIE), Public Good

\section{Introduction}

Military alliances between South Korea and the U.S. and those between Japan and the U.S. were established during the early years of the Cold War. These alliances have experienced a series of transformations since that era. For example, since South Korea and the U.S. signed the Mutual Security Agreement in 1954, the alliance has aimed at providing mutual defenses against outside aggression. During the 2000s, South Korea and the U.S. disagreed over how to handle North Korea whereas China and South Korea have shared anti-Japanese sentiment.

However, China and North Korea have kept longstanding historical and ideological ties with each other, implying that China remains North Korea's most crucial ally and its major trading partner.

A number of studies have investigated the position of the U.S. in its alliance with Japan and South Korea as summarized in Goo and Kim (2009, 2011). Following Okamura's (1991) analysis with regard to the U.S. alliance with Japan against the Soviet Union, several studies have mentioned key aspect regarding the U.S. alliance with South Korea against North Korea (Goo and Kim 2009) and the U.S. alliances with Japan and South Korea, respectively, against China (Goo and Kim, 2011).

However, there has been no study on the U.S. alliances with Japan and with South Korea against the alliance of China and North Korea, which is the main purpose of this study.

This paper examines the role of the U.S. as an ally with respect to the threat from the alliance of China and North Korea. It has been expected to change over time. Two approaches have been attempted: one relies purely on the perspective of public goods and the other relies on the perspective of joint product goods. ${ }^{1}$ The first approach has been proposed by Olson and Zeckhauser (1966), Sandler and Forbes (1980), Murdoch and Sandler (1982, 1984), O’Neal (1990), Sandler (1993), Alesina and Enrico (2006),

\footnotetext{
'Defense goods are treated as non-rival and non-excludable goods shared among allies in a pure public goods approach, but defense goods provide benefits to one specific ally but not to other members of an alliance in a joint product goods approach.
} 
and Goo and Kim $(2009,2011)$. The second has been presented in studies conducted by Sandler (1977), Sandler and Murdoch (1990), Gonzales and Mehay (1991), and Garfinkel (2004). This paper adopts the pure public goods model, in which defense goods are treated as non-rival and non-excludable among allies. Our data did not allow the approach of joint product goods.

The empirical test is based on the simultaneous equations model derived from demand theory (McGuire 1982, 1990, Okamura 1991, Abdollahian and Kang 2008, Goo and Kim 2009) and iterative seemingly unrelated regression (iterative SUR) method is employed.

We analyze the Spill-In Elasticities (hereafter SIE) which measure how much the defense goods purchased by a country can be a substitute for its ally's defense goods. The SIE for an ally's defense goods (Murdoch and Sandler 1984, 1985, Smith 1989, Hilton and $\mathrm{Vu}$ 1991, Shefi and Tishler 2005, Goo and Kim 2011) shows the timedependent importance of American alliances by using threat elasticities. ${ }^{2}$ The alliances resulted from the perceptions of Japan, South Korea, and the U.S. against the threat posed by the China and North Korea alliance (McGuire 1982, 1990, Okamura 1991, Dunne, Ron and Dirk 2005, Goo and Kim 2009). This paper also investigates income and price elasticities ${ }^{3}$ (Okamura 1991, Goo and Kim 2009) to examine the importance of American alliances with South Korea and Japan.

The remainder of this paper is organized as follows. The empirical model derived from the demand function is described in Section II. ${ }^{4}$ Section III describes the data, and Section IV presents the empirical results. Finally, Section V concludes.

\section{The Basic Theory}

Each ally $m$ maximizes its representative utility subject to its budget constraint. The utility function consists of pure public defense goods $\left(X_{1}^{m}\right)$ and civilian goods $\left(X_{2}^{m}\right)$ in the context of the military threat posed by the alliance between China and North Korea $\left(X_{1}^{N C}\right)$; thus, it has the form of $U^{m}=U^{m}\left(X_{1}^{m}, X_{2}^{m} ; X_{1}^{N C}\right)$, where the superscripts $m$ refer to Japan $(J)$, South Korea $(S)$, and the U.S. $(A)$.

\footnotetext{
${ }^{2}$ Threat effect measures how much one country's demand for defense goods is affected by a perceived threat.

${ }^{3}$ Income and price effects are income elasticity and price elasticity.

${ }^{4}$ See Okamura (1991) and Goo and Kim (2009) for details.
} 
The budget constraints of ally $m$ take the form of $I^{m}=P_{1}^{m} X_{1, m}+P_{2}^{m} X_{2}^{m}$, where $P_{i}^{m}$ is the price of good $i$ to ally $m$ and $I^{m}$ is the national income of ally $m$. Defense goods have the properties of non-rivalry and non-excludability in terms of their consumption among allies. Taking into account the public good properties of defense goods, the full income, $F^{m}$, is the sum of its income and the military expenditures of its ally. Thus, the final budget constraints of each ally are, respectively, as follows:

$$
\begin{gathered}
F^{S}=P_{1}^{S}\left(X_{1, S}+X_{1, A S}\right)+P_{2}^{S} X_{2}^{S} \\
F^{A}=P_{1}^{A}\left(X_{1, A}+X_{1, S}+X_{1, J}\right)+P_{2}^{A} X_{2}^{A} \\
F^{J}=P_{1}^{J}\left(X_{1, J}+X_{1, A J}\right)+P_{2}^{J} X_{2}^{J}
\end{gathered}
$$

where $X_{1, S}, X_{1, A}, X_{1, J}, X_{1, A S}$, and $X_{1, A J}$ denote the defense goods of South Korea, the U.S., Japan, the U.S. Armed Forces in South Korea, and the U.S. Armed Forces in Japan, respectively.

We employed a homogeneous generalized-indirect-translog utility function, $\ln V^{m}=\alpha_{0}^{m}+\sum_{i=1} \alpha_{i}^{m} \ln P_{i}^{m}+\frac{1}{2} \sum_{i} \sum_{j} \beta_{i, j}^{m} \ln P_{i}^{m} \ln P_{j}^{m}-\ln \left[F^{m}-\sum_{i} P_{i}^{m} T_{i}^{m}\right]$, where $\alpha_{0}^{m}, \alpha_{i}^{m}, T_{i}^{m}$, and $\beta_{i, j}^{m}$ were parameters. Ally $m$ 's minimum required quantity of goods $i$ is the function of $T_{i}^{m}=\bar{\tau}_{i}^{m}+\tau_{i}^{m} X_{1}^{N C}$, where $\bar{\tau}_{i}^{m}$ is the constant term unaffected by the threat and $\tau_{i}^{m}$ is the coefficient denoting sensitivity to threats to the alliance. Using Roy's identity, we can derive the regression model as follows:

$$
\begin{aligned}
& X_{1}^{S}=\left(\bar{\tau}_{1}^{S}+\tau_{1}^{S} X_{1}^{N C}\right)+\left[\frac{F^{S}}{P_{1}^{S}}-\sum_{j} \frac{P_{j}^{S}}{P_{1}^{S}}\left(\bar{\tau}_{j}^{S}+\tau_{j}^{S} X_{1}^{N C}\right)\right] \times\left(\alpha_{1}^{S}+\sum_{j} \beta_{1, j}^{S} \ln P_{j}^{S}\right)+e_{1}^{S} \\
& X_{1}^{A}=\left(\bar{\tau}_{1}^{A}+\tau_{1}^{A} X_{1}^{N C}\right)+\left[\frac{F^{A}}{P_{1}^{A}}-\sum_{j} \frac{P_{j}^{A}}{P_{1}^{A}}\left(\bar{\tau}_{j}^{A}+\tau_{j}^{A} X_{1}^{N C}\right)\right] \times\left(\alpha_{1}^{A}+\sum_{j} \beta_{1, j}^{A} \ln P_{j}^{A}\right)+e_{1}^{A} \\
& X_{1}^{J}=\left(\bar{\tau}_{1}^{J}+\tau_{1}^{J} X_{1}^{N C}\right)+\left[\frac{F^{J}}{P_{1}^{J}}-\sum_{j} \frac{P_{j}^{J}}{P_{1}^{J}}\left(\bar{\tau}_{j}^{J}+\tau_{j}^{J} X_{1}^{N C}\right)\right] \times\left(\alpha_{i}^{J}+\sum_{j} \beta_{1, j}^{J} \ln P_{j}^{J}\right)+e_{1}^{J}
\end{aligned}
$$


Because the error terms in the above equations ${ }^{6}$ may not be independent for each equation, we estimated them by using the iterative SUR. We included all variables in Equation (4) to (6) because dropping statistically insignificant variables or employing time-lagged versions of threat variables did not improve the overall results of the iterative SUR. Because full income, $F^{m}$, contains an endogenous variable, one lagged full income, $F^{m}(-1)$ was employed as an instrumental variable.

In this paper, SIE is employed to measure how much the defense goods purchased by the U.S. can be a substitute for its allies' defense goods. ${ }^{7}$ If an American ally would like to maintain a close alliance with the U.S., it would be because this ally can benefit from an alliance with the U.S. against outside threats and thus SIE should be negative. To calculate SIE, we use the estimation results of Equation (4) to (6), and then calculate the sensitivity of the U.S.'s ally with respect to a one percentage change of the U.S.'s defense goods.

\section{The Data}

We included two types of goods in the estimate: defense goods $\left(X_{1}^{m}\right)$ and civilian goods $\left(X_{2}^{m}\right)$. We measured defense goods by national defense expenditures in real terms and civilian goods by real expenditures on all other goods in the GDP. Income $\left(I^{m}\right)$ was measured by nominal GDP and price was measured by the price deflator, ${ }^{8}$ but the deflator for government expenditures was used as the defense-goods deflator for Japan and South Korea. Defense goods employed by the alliance between China and North Korea $\left(X_{1}^{N C}\right)$, were measured by the summed defense expenditures of China and North Korea in terms of the real Chinese Yuan. We used annual data from the sample period of 1970 2005. ${ }^{9}$ Because defense goods are pure public goods for both alliances, the purchased amount differs from the consumed amount. The purchased amount is the

\footnotetext{
${ }^{6}$ Under to the summation condition, we can delete the equation for each country's civilian goods for being singular.

${ }^{7}$ SIE is the sensitivity of one country's demand for actual military expenditures with respect to its ally's military expenditures. It is explained in Murdoch and Sandler (1984, 1985), Smith (1989), Hilton and Vu (1991), and Shefi and Tishler (2005).

${ }^{8}$ The prices of other goods were calculated according to the following equation (GDP deflator - Price deflator of national defense $\times$ Portion of GDP dedicated to national defense) / Portion of GDP dedicated to other goods.

${ }^{9}$ The following data sources were used in the estimates: the datasets for South Korea and North Korea were obtained from the Defense White Paper (Ministry of National Defense) and The Monthly Bulletin (the Bank of Korea); data on Japan were obtained from the Japan Statistical Yearbook (Statistics Bureau); data on the U.S. were obtained from www.bea.gov (Bureau of Economic Analysis); and data on China were obtained from the China Statistical Yearbook (National Bureau of Statistics of China).
} 
actual expenditure in each country's budget and the consumed amount is the purchased amount plus the amount of the purchased defense goods of an ally.

We assumed that the U.S. forces stationed in South Korea were utilized by South Korea and that the U.S. forces stationed in Japan were utilized by Japan. Thus, the U.S. forces stationed in each country can be calculated by multiplying the real U.S expenditures by the ratio of U.S. military personnel in each country to total U.S. military personnel. ${ }^{10}$ The Chinese and North Korean military expenditures were considered as a proxy for the threat posed by the alliance of China and North Korea (Goo and Kim 2009, 2011).

\section{The Importance of the United States to its Allies}

We first calculated the results of Equation (4) to (6), which are reported in the Table A of Appendices. We then used the estimated coefficients to calculate the elasticities of an American ally with respect to a one percentage change of the U.S.'s defense goods.

Table B in Appendices shows the US military expenditure for South Korea and Japan.

Table 1 presents SIE, which measures the sensitivity of a country's demand for actual military expenditures in response to changes in its ally's military expenditures. The mathematical formula for SIE is

$$
\text { Spill-In-Elasticity }=\frac{\frac{d X_{1, S}}{X_{1, S}}}{\frac{d X_{1, A S}}{X_{1, A S}}}
$$

which measures the sensitivity of South Korea's demand for actual military expenditures in response to changes in the U.S.'s military expenditures. The threat effect calculates the partial derivative of the defense goods purchased or consumed by a country with respect to the threat from China and North Korea. The SIE shows a

\footnotetext{
${ }^{10}$ The number of U.S. military personnel stationed in South Korea was obtained from the Korean Ministry of National Defense (2008) and the number of U.S. military personnel stationed in Japan was obtained from the Heritage Foundation (2009).
} 
country's close relationship with its ally and thus the importance of its ally while the threat effect shows an increase in military expenditures in response to a threat. Positive threat effects with negative SIE would be considered to benefits from an alliance. Because of the public good properties of the defense goods, the SIE should normally be negative for close allies. By using the arithmetic mean of the SIE, Table 1 shows a larger negative SIE for South Korea than for U.S., implying that the U.S. is important for South Korea as a close military ally during the entire period.

Table 1. Spill-In Elasticities of Demand for Defense Goods

\begin{tabular}{|c|c|c|c|c|}
\hline \multirow{2}{*}{} & \multicolumn{2}{|c|}{ South Korea-U.S. Alliance } & \multicolumn{2}{c|}{ Japan-U.S. Alliance } \\
\cline { 2 - 5 } & South Korea & U.S. & Japan & U.S. \\
\hline $1970 \sim 1979$ & -0.220 & -0.100 & 0.004 & -0.035 \\
\hline $1980 \sim 1989$ & -0.441 & -0.061 & 0.013 & -0.053 \\
\hline $1990 \sim 1999$ & -0.611 & -0.048 & 0.267 & -0.110 \\
\hline $2000 \sim 2005$ & -1.040 & -0.023 & -0.229 & -0.082 \\
\hline
\end{tabular}

(Note) Each elasticity value is the arithmetic mean for each sample period.

The negative SIEs imply that the U.S.'s purchased defense goods are substitutes for its ally's defense goods, confirming that South Korea and the U.S. maintain a close alliance, because the two countries can benefit from an alliance against outside threats.

Japan started to form a close alliance with the U.S. in the 2000 s, as reflected in the response of consumed goods to threats to their alliance. Japan had a strong incentive to maintain its alliance with the U.S. against the threat of the Soviet Union (Okamura 1991) but it is only recently that Japan seemed motivated to maintain an alliance with the U.S. against China (Goo and Kim 2012). Hence, the U.S. began to become important ally for Japan only in the 2000s.

In terms of the size of the SIE, it is clear that Japan's SIEs were higher (larger in absolute value) than those of the U.S. in the 2000s. One interpretation is that Japan considers the U.S. to be a more important ally than vice versa in the context of the China-North Korea alliance. Additionally, the SIEs of the U.S. were lower than those 
of South Korea in the 2000s. Thus, South Korea may also regard the U.S. as a more important ally than vice versa. The U.S.'s SIE in the context of its alliance with South Korea is lower than its SIE with Japan in the 2000s. This indicates that the U.S. regards South Korea as less important than Japan as an ally, which may reflect South Korea's subordinate position as an ally of the U.S.

Table 2 shows the sensitivity of each country's defense goods in response to oneunit increase in defense goods from external threats. The threat elasticities for purchased goods are $\frac{\left(d X_{1, S} / X_{1, S}\right)}{\left(d X_{1, N C} / X_{1, N C}\right)}$, which measures the sensitivity of South Korea's demand for actual military expenditures in response to changes the China-North Korea alliance's military expenditures. Overall, the threat of the military alliance between China and North Korea had a negative effect on South Korea during this period. The U.S., however, responded positively to the threats from 2000, and Japan reacted positively from since 1990 in terms of purchased defense goods, and from 2000 in terms of consumed goods. These results imply that South Korea did not regard the ChinaNorth Korea alliance as a significant threat but that Japan and the U.S. have recently recognized this military alliance as a serious threat.

These results reflect different reactions among Japan, South Korea, and the U.S. to the threat of the China-North Korea alliance.

Table 2. Threat Elasticities for Purchased and Consumed Defense Goods

\begin{tabular}{|c|c|c|c|c|c|c|}
\hline & \multicolumn{2}{|c|}{ South Korea } & \multicolumn{2}{c|}{ U.S. } & \multicolumn{2}{c|}{ Japan } \\
\cline { 2 - 8 } & $\begin{array}{c}\text { Purchased } \\
\text { goods }\end{array}$ & $\begin{array}{c}\text { Consumed } \\
\text { goods }\end{array}$ & $\begin{array}{c}\text { Purchased } \\
\text { goods }\end{array}$ & $\begin{array}{c}\text { Consumed } \\
\text { goods }\end{array}$ & $\begin{array}{c}\text { Purchased } \\
\text { goods }\end{array}$ & $\begin{array}{c}\text { Consumed } \\
\text { goods }\end{array}$ \\
\hline $1970 \sim 1979$ & -0.034 & -0.028 & -0.086 & -0.076 & -0.221 & -0.222 \\
\hline $1980 \sim 1989$ & -0.070 & -0.048 & -0.040 & -0.035 & -0.414 & -0.420 \\
\hline $1990 \sim 1999$ & -0.194 & -0.119 & -0.085 & -0.073 & 0.274 & -0.145 \\
\hline $2000 \sim 2005$ & -0.504 & -0.245 & 0.261 & 0.242 & 1.887 & 1.065 \\
\hline Average & -0.171 & -0.097 & -0.013 & -0.009 & 0.227 & -0.036 \\
\hline
\end{tabular}

(Note) Each elasticity value is the arithmetic mean for each sample period. 
Data show that the threat effects on South Korea have been negative but that the threat effects on Japan and the U.S. have recently begun to elicit positive reactions, reflecting the beginning of the recognition, of the common interests of Japan and the U.S. in deterring threats from the China-North Korea alliance. After the World War II, the Soviet Union was the most significant threat to Japan and the U.S., leading Japan and the U.S. to establish a military alliance against the threat from the Soviet Union during the Cold War (Okamura 1991). However, after the Cold War, the major point of power balance in Asia moved from the Soviet Union to China, further, the rapid economic growth of China has bean materialized (Goo and Kim 2012).

Given these changes, Japan and the U.S. have recently come to consider the alliance as an exogenous threat, South Korea, however, did not engage in a competitive arms race with this alliance, even though North Korea has actually posed a substantial threat to South Korea.

In the context of North Korea's threat, Goo and Kim (2009) shows that South Korea is sensitive to the threat posed by North Korea but that South Korea does not consider China a significant threat even though Japan and the U.S. have recognized China as a serious threat since the 1990s and the 2000s. Thus, South Korea has not considered the combined threat to be as important as the threat from North Korea.

Another noteworthy result emerged from comparing the effects of the threats to Japan and to the U.S., Japan responded more actively than the U.S. to these threats in the 2000s, implying that these threats pose a more substantial burden to Japan possibly because of its closer geographical proximity to China and North Korea (Murdoch and Sandler 1984, 1985, Goo and Kim 2009). Additionally, the effects of the threat on purchased goods were larger than those on consumed goods in both Japan and the U.S. Their percentage of purchased goods changes more radically than does the percentage of consumed goods. Our results also indicate that Japan considered the U.S. to be a more important ally than the U.S. did during 2000 2005.

\section{Conclusions}

This paper analyzed how Japan and South Korea consider the U.S. as their ally by using the SIE and threat effects. South Korea considers the United States as an important ally during all periods, but Japan began to form a close relationship with the 
United States only recently. South Korea is found to be a less important ally to the U.S. than Japan according to SIE estimates.

In response to threats from the China-North Korea alliance, South Korea did not increase military expenditures, whereas Japan and the United States showed positive responses to recent increases in the threat posed by this alliance. The recent Japanese reactions to threats from the China-North Korea alliance have been particularly sensitive, as compared with those during the earlier sample periods. This implies that Japan and the United States have begun to respond more actively to the recent increase in military expenditures spent by the China-North Korea alliance.

This paper suggests that the three countries hold different views of the threat from the China-North Korea alliance.

Received 26 June 2013, Revised 10 March 2014, Accepted 25 March 2014

\section{References}

Abdollahian, Mark, and Kyungkook Kang (2008), "In Search of Structure: The Nonlinear Dynamics of Power Transitions International Interactions", International Interactions, 34: 333-357.

Alesina, Alberto, and Enrico Spolaore (2006), "Conflict, Defense Spending, and the Number of Nations", European, Economic Review, 50: 91-120.

Conybeare, John A. C., and Todd Sandler (1990), “The Triple Entente and The Alliance 1880 1914: A Collective Goods Approach“, American Political Science Review, 84: 197-206.

Dunne, Paul J., Ron Smith, and Dirk Willenbockel (2005), "Models of Military Expenditure and Growth: A Critical Review", Defence and Peace Economics, 16: 449461.

Garfinkel, Michelle R. (2004), "Stable Alliance Formation in Distributional Conflict", European Journal of Political Economy, 20: 829-852.

Gonzales, Rodolfo A., and Stephen L. Mehay (1991), "Burden Sharing in the NATO 
Alliance: An Empirical Test of Alternative Views", Public Choice, 68: 107-116.

Goo, Young-Wan, and Seung-Nyeon Kim (2009), “A Study on the Military Alliance of South Korea-United States with the Existence of Threat from North Korea: A Public Good Demand Approach", Empirical Economics, 36: 597-610.

Goo, Young-Wan, and Seung-Nyeon Kim (2012), "Time-Varying Characteristics of South Korea-United States and Japan-United States Military Alliances under Chinese Threat", Defense and Peace Economics, 23: 95-106.

Heritage Foundation (2009), "Global U.S. Troop Deployment Dataset”, http://www. heritage.org/Research/NationalSecurity/troopsdb.cfm.

Hilton, Brian, and Anh Vu (1991), "The McGuire Model and The Economics of The NATO Alliance", Defense Economics, 2: 105-121.

“Korea Ministry of National Defense", Defense White Paper.

McGuire, Martin C. (1982), "US Assistance, Israeli Allocation, and the Arms Race in the Middle East", Journal of Conflict Resolution, 26: 199-235.

McGuire, Martin C. (1990), "Mixed Public-Private Benefit and Public Goods Supply, with an Application to the NATO Alliance", Defense Economics, 1: 17-35.

Murdoch, James C., and Todd Sandler (1982), "A Theoretical and Empirical Analysis of NATO”, Journal of Conflict Resolution, 26: 237-263.

Murdoch, James C., and Todd Sandler (1984), "Complimentarily, Free Riding, and the Military Expenditure of NATO Allies", Journal of Public Economics, 25: 83-101.

Murdoch, James C., and Todd Sandler (1985), “Australian Demand for Military Expenditure: 1961-1979”, Australian Economic Papers, 44: 142-153.

Okamura, Minoru (1991), "Estimating the Impact of the Soviet Union's Threat on the United States-Japan Alliance: A Demand System Approach", Review of Economics and Statistics, 73: 200-207.

Olson, Mancur Jr., and Richard Zeckhauser (1966), “An Economic Theory of Alliances”, Review of economics and Statistics, 48: 266-279.

Oneal John R. (1990), "Testing the Theory of Collective Action: NATO Defense Burdens, 1950-1984", Journal of Conflict Resolution, 34: 426-448. 
Sandler, Todd (1977), "Impurity of Defense: An Application to the Economics of Alliances", Kyklos, 30: 443-460.

Sandler, Todd, and John F. Forbes (1980), "Burden Sharing, Strategy, and the Design of NATO”, Economic Inquiry, 18: 425-444.

Sandler, Todd, and James C. Murdoch (1990), "Nash-Cournot or Lindahl Behavior?: An Empirical Test for the NATO Allies”, Quarterly Journal of Economics, 105: 875-894.

Shefi, Yoad, and Asher Tishler (2005), "The Effects of the World Defense Industry and US Military Aid to ISRAEL on the ISRAEL Defense Industry: A Differentiated Products Model", Defence and Peace Economics, 16: 427-448.

Smith, Ronald P. (1989), "Models of Military Expenditure", Journal of Applied Economics, 4: 345-359. 


\section{Appendices}

Table A.

The Estimated Coefficient for the Alliance of China-North Korea

$$
\begin{aligned}
& X_{1}^{S}=\left(\bar{\tau}_{1}^{S}+\tau_{1}^{S} X_{1}^{N C}\right)+\left[\frac{F^{S}}{P_{1}^{S}}-\sum_{j} \frac{P_{j}^{S}}{P_{1}^{S}}\left(\bar{\tau}_{j}^{S}+\tau_{j}^{S} X_{1}^{N C}\right)\right] \times\left(\alpha_{1}^{S}+\sum_{j} \beta_{1, j}^{S} \ln P_{j}^{S}\right)+e_{1}^{S} \\
& X_{1}^{A}=\left(\bar{\tau}_{1}^{A}+\tau_{1}^{A} X_{1}^{N C}\right)+\left[\frac{F^{A}}{P_{1}^{A}}-\sum_{j} \frac{P_{j}^{A}}{P_{1}^{A}}\left(\bar{\tau}_{j}^{A}+\tau_{j}^{A} X_{1}^{N C}\right)\right] \times\left(\alpha_{1}^{A}+\sum_{j} \beta_{1, j}^{A} \ln P_{j}^{A}\right)+e_{1}^{A} \\
& X_{1}^{J}=\left(\bar{\tau}_{1}^{J}+\tau_{1}^{J} X_{1}^{N C}\right)+\left[\frac{F^{J}}{P_{1}^{J}}-\sum_{j} \frac{P_{j}^{J}}{P_{1}^{J}}\left(\bar{\tau}_{j}^{J}+\tau_{j}^{J} X_{1}^{N C}\right)\right] \times\left(\alpha_{i}^{J}+\sum_{j} \beta_{1, j}^{J} \ln P_{j}^{J}\right)+e_{1}^{J}
\end{aligned}
$$

\begin{tabular}{|c|c|c|c|c|}
\hline & Coefficient & Std. Error & $t$-Statistic & $p$-value \\
\hline $\bar{\tau}_{1}^{S}$ & 33.698 & 3.347 & 10.069 & 0.000 \\
\hline$\tau_{1}^{S}$ & -0.087 & 0.040 & -2.164 & 0.033 \\
\hline $\bar{\tau}_{2}^{S}$ & 42.208 & 33.697 & 1.253 & 0.214 \\
\hline$\tau_{2}^{S}$ & -0.532 & 0.396 & -1.343 & 0.183 \\
\hline$\alpha_{1}^{S}$ & 0.099 & 0.033 & 3.000 & 0.004 \\
\hline$\beta_{1,1}^{S}$ & 0.351 & 0.190 & 1.842 & 0.069 \\
\hline $\bar{\tau}_{1}^{A}$ & 195.297 & 89.634 & 2.179 & 0.032 \\
\hline$\tau_{1}^{A}$ & 13.517 & 5.883 & 2.298 & 0.024 \\
\hline $\bar{\tau}_{2}^{A}$ & -2.393 & 125.355 & -0.019 & 0.985 \\
\hline$\tau_{2}^{A}$ & -18.742 & 8.378 & -2.237 & 0.028 \\
\hline$\alpha_{1}^{A}$ & -2.567 & 0.275 & -9.346 & 0.000 \\
\hline$\beta_{1,1}^{A}$ & -12.194 & 2.760 & -4.419 & 0.000 \\
\hline $\bar{\tau}_{1}^{J}$ & 22654.120 & 2750.393 & 8.237 & 0.000 \\
\hline$\tau_{1}^{J}$ & -178.375 & 61.301 & -2.910 & 0.005 \\
\hline $\bar{\tau}_{2}^{J}$ & 19247.420 & 2291.209 & 8.401 & 0.000 \\
\hline$\tau_{2}^{J}$ & -152.016 & 52.172 & -2.914 & 0.005 \\
\hline$\alpha_{1}^{J}$ & 0.540 & 0.002 & 235.127 & 0.000 \\
\hline$\beta_{1,1}^{J}$ & 0.247 & 0.000 & 838.991 & 0.000 \\
\hline & & & & \\
\hline
\end{tabular}


Table B. Real expenditures of the U.S. on defense goods for South Korea and Japan (in billion US dollar)

\begin{tabular}{|c|c|c|}
\hline & $\begin{array}{c}\text { Military expenditures of the U.S. } \\
\text { for South Korea } X_{1, A S}\end{array}$ & $\begin{array}{c}\text { Military expenditures of the U.S. } \\
\text { for Japan } X_{1, A J}\end{array}$ \\
\hline 1980 & 5.9 & 7.0 \\
\hline 1990 & 9.3 & 10.6 \\
\hline 2000 & 10.0 & 10.9 \\
\hline 2005 & 10.4 & 12.4 \\
\hline
\end{tabular}

